INTERNATIONAL CONFERENCE ON COMMUNICATION AND MEDIA 2020

\title{
SOME LIKE IT HOAX : LESSONS IN REGULATING FAKE NEWS IN MALAYSIA
}

\author{
Hafidz Hakimi Haron (a)*, Farid Sufian Shuaib (b), Nadiah Arsat (c) \\ *Corresponding author \\ (a) Lecturer, Faculty of Law, Multimedia University, Melaka, Malaysia, hafidz.haron@mmu.edu.my \\ (b) Professor, Ahmad Ibrahim Kuliyyah of Laws, International Islamic University Malaysia, Selangor, Malaysia, \\ farid@iium.edu.my \\ (c) Lecturer, Foundation in Science (Information and Communications Technology), Melaka-Manipal Medical \\ College, Melaka, Malaysia, nadiah.arsat@manipal.edu.my
}

\begin{abstract}
The growth of digital technology promotes the positive impact of the usage of digital based media as the main source of information. Although the development has a significant positive impact to the digital economy, it is unfortunate that the online media has become a breeding ground for dissemination of false information. Worse, news from unverified sources has often been carelessly quoted by the mainstream press which shows a remarkably questionable practices and consequently shows possible regulatory gap in the enforcement of press ethical conduct. Yet, existing laws on dissemination of false information had often being criticized as draconian, anti-democratic, and viewed as the instrument of the state control over free speech. This sentiment later contributed to the abolishment of the Anti-Fake News Act 2018 - just a year after it was enacted. Nevertheless, controlling propagation of fake news has proven to be challenging to the authorities. The episodes of the spread of fake news in regard to the Covid-19 pandemic in Malaysia had stretched the authorities to choose a stricter offence under the Penal Code rather than the usual anti-fake news legislations such as the Printing Presses and Publication Act 1984 and the Communications and Multimedia Act 1998. Thus, the primary objective of this paper is to revisit the development of fake news regulatory mechanism in Malaysia, and to recommend any possible improvement to curb it in the future. The paper adopts the method of textual analysis of the legislation as well as semi-structured interviews.
\end{abstract}

2357-1330 (c) 2021 Published by European Publisher.

Keywords: Constitutional law, freedom of press, human rights, media council, Press ethics, press council 


\section{Introduction}

Without a doubt, the current COVID-19 pandemic epitomizes a substantial trial to the global human wellbeing. Unfortunately, misinformation pertaining to the pandemic has proliferated in the media which may come in many forms (Pennycook et al., 2020). The misinformation in respect to the pandemic has become so grave that even some scholars had coined up a new term in that regard, known as 'infodemic' (Cinelli et al., 2020; Zainul, 2020a). In Malaysia alone, as of 12 July 2020, 266 investigation papers had been opened in association with the spread of fake Covid-19 news, of which 172 cases are still under investigation, 12 given warning notices, 30 prosecuted in court, 13 still on trial, while 17 pleaded guilty (Bernama, 2020b). Since the beginning of the pandemic, the Malaysian government agencies had worked all around the clock on social media and official portals to debunk myths and alert the public to scams connected to the pandemic (Leong, 2020). This however is not new in Malaysia. With the growth of information technology especially social media and instant messaging platforms (Mohd Yatid, 2019), the internet soon became a breeding ground of false information or 'fake news'. Some scholars define 'fake news' as fabricated information that mimics news media content in form but not in organizational process or intent (Lazer et al., 2018, p. 1094). Others regards them as not similar to disinformation, but a species of disinformation (Gelfert, 2020). Several scholars attributed the term 'fake news' to the Donald Trump's presidential campaign in 2016, (Bakir \& McStay, 2018, p. 1; Fernandez, 2019, p. 174) however some others argue that 'fake news' existed since the 6th Century (Posetti \& Matthews, n.d.). Despite several laws being placed in order to curb dissemination of fake news; including the Communications and Multimedia Act 1998, the Penal Code, the Printing Presses and Publication Act 1984, and the former Anti Fake News Act 2018, it seems to have failed to address the issue properly (Daud, 2016). Even though regulating dissemination of fake news is essential, to ensure that the constitutional guarantees of freedom of speech in Malaysia is properly observed is also equally important.

\section{Problem Statement}

Despite the many laws in existence designed to curb dissemination of fake news in Malaysia, those laws has been rendered as ineffective and has been subjected to criticisms. This includes, the definition of fake news that has not been clearly defined and some even criticized that the implementation of those laws are selective. The penalties enforced under them are also under scrutiny as some deemed it to be excessive and can potentially be used as a weapon to impede freedom of speech. Alternative apparatus, such as self-regulation mechanisms to combat fake news in Malaysia is urgently needed.

\section{Research Questions}

Accordingly, the researchers identify there are two research questions in this paper:

- Whether the current laws that regulate dissemination of fake news in Malaysia is adequate?

- Whether there is a need for alternative enforcer in order to combat dissemination of fake news in Malaysia, apart from the existing legal measures? 


\section{Purpose of the Study}

The main objective of this research is, firstly to learn and to re-examine our current legal approach in combating creation and dissemination of fake news in Malaysia. Secondly, is to explore and to suggest alternative avenues to achieved the previously mentioned objective.

\section{Research Methods}

This paper adopts qualitative method as it provides a better understanding on the current legal approach in combating fake news in Malaysia. Thus, semi-structured interviews were conducted involving key participants of the related field, comprise of 1) An Editorial Executive Advisor, Grup Sinar Karangkraf, 2) A representative from the National Union of Journalists Peninsular Malaysia (NUJM), 3) A representative from Coalition for Clean and Fair Elections (BERSIH 2.0) and 4) A representative from The Malaysian Press Institute (MPI). The researchers will use purposive sampling as this technique is designed to reach experts or specialized population. This provides the chance to discover opinions and suggestions from these relevant individuals and thus maintaining originality of this paper. Besides, this research employs doctrinal-based method in gathering research data. The doctrinal-based research will be carried out comprehensively as part of finding relevant key sources; such as legal provisions, case laws, and other relevant primary data materials. Additionally, we will also conduct data collection on secondary sources by using library-based and online research.

\section{Findings}

\subsection{Anti-Fake News Laws And Its Implementation}

Accordingly, there are legislations enacted in Malaysia as legal means to combat dissemination of fake news. Regardless, in the recent years, the authors identified that there are several key penal legislations that has been used in order to achieve aforementioned objective.

Section 505(b) of the Penal Code basically criminalizes dissemination of false reports, either it is made orally or in writing, irrespective of medium, offline or online. The main essence for conviction under this provision is not only limited to dissemination of false facts but those facts must cause a public fear or alarm. In the recent months, Section 505(b) has been widely used as a tool to combat dissemination of fake news in regards to Covid-19 (Bernama, 2020a), where upon conviction the guilty party may be subjected to two years imprisonment or with fine, or both. The usage of such provision had invited criticisms from Human Rights advocates, including the Article 19, where they expressed concerns over the actions of the Malaysian government primarily relying on criminal proceedings in stemming dissemination misinformation. In this respect, they believed that such legal measure should only be used as a last resort for the 'most serious and dangerous forms of speech' (ARTICLE 19, 2020). The main concern over this provision is due to its criminal liability which is much dependent on the subjectivity of response of the listener, of which whether it is likely to cause alarm or otherwise (Zainul, 2020a). This later, may give a leverage to the listener to silence critics against him (Human Rights Watch, 2015). 
The other tool that being frequently used to curb fake news in Malaysia is through Section 8A of the Printing Presses and Publications Act 1984 (Printing Presses and Publications Act 1984 s. 8(A), n.d.). This provision, enacted in 1987 was passed with intention to be a tool to curb dissemination of 'malicious' false information among the printed press industry. Opposition politicians (Sufian Shuaib \& Hakimi Haron, 2019) and social activists have often come under scrutiny of said provision. The inadequacy on defining what amounts to 'false information' under the Act has often drew criticisms over the abuse of law. The excessive requirement under the provision to dispel the element of malice to the false news, which is abled by default (Nawang \& Mustaffa, 2017), is also concerning. It should be noted that, as stated under Section 8A (2) of the Act, it is required that the publisher had took all reasonable steps to verify the authenticity of the news (Faruqi, 2008). This however, would later be proven to be a huge obstacle among genuine whistle blowers in regards to proving whether the publisher had took all the required steps itself since its subjective.

Nevertheless, since mainstream printed press publications has been tremendously in decline locally in the recent years (Haron et al., 2019), so do prosecutions under Section 8A of the PPA 1984. The increasing reliability over online based news as the main source of information had further put the need for regulations over online content into a spotlight in the recent years (Daud, 2019). In general, two provisions under the Communications and Multimedia Act 1998 (Communications and Multimedia Act 1998 s. 211,233 , n.d.) had been frequently used to criminalize creation or dissemination of online fake news, namely Section 211 and Section 233 (Daud, 2019). Section 211 of CMA 1998 identifies 'fake news' under a broad categorisation known as 'offensive content' (Daud \& Zulhuda, 2020). While Section 233 of CMA 1998 further illegalized 'improper use of network facilities or network services for the purpose of (inter alia) communication of false content' (Daud, 2016, p. 132). In terms of implementation, Section 233 is meant to regulate websites that offers interactive content, whereas, Section 211 of the Act regulates online static content such (Daud, 2019). This explains why most cases in regards to dissemination of online fake news relating to Covid 19 recently were charged and prosecuted under Section 233 instead of Section 211 since most of them involved interactive content such as social media. Again, the vagueness of terminologies stipulated in both sections proved to be a problem, including the word 'false or offensive' information in the Act (Daud, 2019). Thus, since the prohibitory word is vague in nature, it is prudent to read it together with the Content Code, which is the very approach embraced by the Communications and Multimedia Content Forum (CMCF) (Daud \& Zulhuda, 2020). A person may be sentenced to maximum fine of RM 50,000, or an imprisonment for a term not more than a year or both, if convicted under Section 211 or Section 233 of the Act.

Based on these shortcomings, the government tried to solidify the existing legal framework by introducing the Anti-Fake News Act 2018 (Anti-Fake News Act 2018 s. 9, n.d.). The Act however was largely criticized by many. At first the Bill of the Act was viewed as to be introduced hastily and 'illconceived' (Fernandez, 2019, p. 186), as it only took 2 weeks for the bill to be passed as a law since it was first debated (Daud \& Zulhuda, 2020). This led to the believe that AFNA 2018 was meant to suppress public opinion and was politically motivated (Mohd Yatid, 2019). Apart from that, the term fake news in AFNA 2018 was widely contentious (Fernandez, 2019) and subjective as it defines fake news to be any information that is 'false or partly false' (Daud \& Zulhuda, 2020). At the same time, AFNA 2018 
were also accused to be 'introduced without consulting key-stakeholders, stricken with serious doubts of constitutionality, and was badly drafted' (Fernandez, 2019, p. 186). Apart from broadly defining what would be amounting to a 'fake news', the Act was also criticize for its severe punishment, which carries a maximum ten years imprisonment or RM500,000 in fine - which is an equivalent punishment for a crime committed against the state (Daud \& Zulhuda, 2020). The other criticism of AFNA 2018 is in regard to the authority of the Court to demand removal of any publication of fake news under Section 7 where there is no clear stipulation under the Act that provides a time frame to the publisher to do so. In addition to that, the Court is also empowered by Section 9 of the Act to direct the Malaysian Communication and Multimedia Commission (MCMC) and the Police to remove said publication. Unfortunately, unnecessary abuse may occur since measures can be taken to remove such publication were not clearly mentioned in the Act (Daud \& Zulhuda, 2020). The AFNA 2018 however was later repealed on October 2019 by the Pakatan Harapan's government, just about a year after it was passed on April 2018 (Buchanan, 2019b).

Apart from the aforementioned, civil actions can also be taken against the 'fake news' publisher under tort of defamation. Defamation suits has a chilling effect among the press, as a representative from the NUJM revealed that $90 \%$ NUJM's fund had been disbursed to assist its members for defamation suit cases. According to her, the press had been threatened with mega suits to deter them from exercising their function as a public whistle-blower. It is also unsurprising to note that that all of our interview respondents from the press industry found that the legal restrictions imposed upon them are excessive. Their views are also shared by other respondents.

\subsection{Alternative Enforcers: Self-Regulation and Press Council to the rescue?}

Earlier discussions shows that relying on legal means alone is not efficient enough to curb dissemination of fake news, as more cases has been reported on a daily basis (Daud \& Zulhuda, 2020). Even though many noted that there is a crucial need to regulate the creation and dissemination of fake news (Daud, 2019), legal measures are often viewed as 'a major impediment to constitutional guarantees to free speech (Fernandez, 2019). Other alternatives apart from statutory means should be seriously considered.

Self-regulation briefly refers to regulations that are administered, specified and enforced by the regulated organizations (Bartle \& Vass, 2005), and occurs in the absence of state authority over a specific subject matter (Hasim \& Merican, 2002; Kleinsteuber, 2004). At the press industry level, several media accountability system can be enforced in order to ensure that press ethics is properly observed (Bertrand, 1997), including disseminating accurate and fair reports. The respondents from the NUJM and an Editorial Executive Advisor of Grup Sinar Karangkraf agrees that self-censorship plays a huge role in shaping press norms in Malaysia. In fact, an Editorial Executive Advisor of Grup Sinar Karangkraf stressed that it is the first layer to ensure accountability among the press companies in news reporting. However, since the compliance is voluntary in nature, thus adherence to them may be questionable especially in absence of external pressure (Bertrand, 1997). On the other hand, the respondent from the NUJM also criticized the effectiveness of it, as she believed that news were not reported accurately, due to external political pressure of the 'interested parties' against the press industry. This scenario was also acknowledged by an Editorial Executive Advisor of Grup Sinar Karangkraf where, freedom of press in 
Malaysia is not only limited by law, but also the will of their 'political masters', which may results into manipulated information. This further proves the subjectivity of what is amounting to 'fake news', especially among the mainstream press industry.

Self-verification is also an important mode of self-regulation especially among news consumers. Sebenarnya.my portal is one of the websites whereby, Malaysians able to verify the authenticity of any news from most available online platforms in the country. The effectiveness the portal in encountering fake news is also attributed by the success of the government's Rapid Response Team who managed to shot down 205 fake news in just a month after its establishment on March 2020 (The Star, 2020). Apart from the mentioned portal, the government also use social media to educate the public regarding to fake news (Buchanan, 2019a). Regardless of the initiative taken by the Malaysian government in countering fake news through information and education, some might argue that such move upholds only the government of the truth (Daud \& Zulhuda, 2020). Private and the state versions of 'truths' may collide, thus asking the question, which truth shall prevail? (Allcott \& Gentzkow, 2017). Would a one sided truth compliment the constitutional guarantees to access of information?

Another major force that can be used to combat fake news is through a Press or Media Council. However it is still yet to be properly instituted as this article is written (Haron et al., 2019; Hasim \& Merican, 2002; Sufian Shuaib \& Hakimi Haron, 2019; Wariya, 2017). Press Council may come in various forms and names (Hasim \& Merican, 2002). One of the major role of the Council is to enrich professionalism of the members of the press (Wariya, 2017). Stern actions taken by the government against the media practitioners in combating infodemic recently had raised some alarm among the journalist fraternities and free press advocates (Centre of Independent Journalism, 2020). Punitive actions taken by the authorities are viewed as counter-productive in warranting the news provider holding itself to a higher standard (Zainul, 2020b). Accordingly, these necessitates the establishment of an independent, transparent, self-regulatory body such as a Press Council (Centre of Independent Journalism, 2020) in order to avoid incidents of misreporting (Zainul, 2020b). Through ensuring professional standard met by the members of the press, such council will be empowered with the mandate to reprimand members who failed to meet the standards (Cohen-Almagor, 2014; Haron et al., 2019; Zainul, 2020b).

\section{Conclusion}

Learning from Malaysian experience in regulating fake news in the country, it can be concluded that pure statutory approach is ineffective in curbing the creation and dissemination of fake news. Related future legislation with the same spirit as the former AFNA 2018, should provide specific objectives and clear applicability to the offence concerned, irrespective of medium. Furthermore, any proposed future legislation should only be applicable to intentional creation and/or spread of fake news or disinformation. Additionally, penal legislation on matter concerned only works by joining hands with other semi or nonlegal measures. The establishment of independent external overseeing self-regulatory body such as a Press Council, would greatly improve the standard of journalism, thus reducing creation or dissemination of unverified information. 


\section{References}

Allcott, H., \& Gentzkow, M. (2017). Social Media and Fake News in the 2016 Election. Journal of Economic Perspectives, 31(2), 211-236. https://doi.org/10.1257/jep.31.2.211

Anti-Fake News Act 2018 s. 9 (My, n.d.). Retrieved from http://www.ilo.org/dyn/natlex/natlex4.detail?p_lang=en\&p_isn=106305\&p_country=MYS\&p_cou $\mathrm{nt}=200 \&$ p_classification $=01.05 \& \mathrm{p} \_$classcount $=10$

ARTICLE 19. (2020). Malaysia: Stop using repressive laws to counter misinformation about coronavirus. Retrieved on August 12, 2020 from https://www.article19.org/resources/malaysiastop-using-repressive-laws-to-counter-misinformation-about-coronavirus/

Bakir, V., \& McStay, A. (2018). Fake News and The Economy of Emotions: Problems, causes, solutions. Digital Journalism, 6(2), 154-175. https://doi.org/10.1080/21670811.2017.1345645

Bartle, I., \& Vass, P. (2005). Self-regulation and the regulatory state: A survey of policy and practice. Centre for the Study of Regulated Industries. Bath.

Bernama. (2020a, March 18). Police open 40 investigation papers over fake news on Covid-19. The New Straits Times.

Bernama. (2020b, July 12). 266 investigation papers on Covid-19 fake news so far, says senior minister. The Malay Mail. https://www.malaymail.com/news/malaysia/2020/07/12/266-investigationpapers-on-covid-19-fake-news-so-far-says-senior-minister/1883753

Bertrand, C. (1997). Quality Control: Media Ethics and Accountability Systems. Paris: Presses Universitaires de France.

Buchanan, K. (2019a). Initiatives to Counter Fake News: Malaysia. August 14, 2020, https://www.loc.gov/law/help/fake-news/malaysia.php

Buchanan, K. (2019b). Malaysia: Bill to Repeal Anti-Fake News Act Passed. August 12, 2020, https://www.loc.gov/law/foreign-news/article/malaysia-bill-to-repeal-anti-fake-news-act-passed/

Centre of Independent Journalism. (2020). CSOs worried over "stern action" on online media that misreport. August 14, 2020, https://cijmalaysia.net/csos-worried-over-plan-to-take-action-againstonline-media-that-misreport/

Cinelli, M., Quattrociocchi, W., Galeazzi, A., Valensise, C. M., Brugnoli, E., Lucia, A., Zola, P., Zollo, F., Scala, A. (2020). The COVID-19 Social Media Infodemic. Scientific Reports, 10(16598), 1-18. https://doi.org/https://doi.org/10.1038/s41598-020-73510-5

Cohen-Almagor, R. (2014). Press Self-Regulation in Britain: A Critique. Science and Engineering Ethics, 21(1), 159-181. https://doi.org/10.1007/s11948-014-9538-8

Communications and Multimedia Act 1998 s. 211,233 (My, n.d.). Retrieved from https://www.mcmc.gov.my/skmmgovmy/media/General/pdf/Act588bi_3.pdf

Daud, M. (2016). A Legal Analysis Of Digital Expression And Online Content Regulation In Malaysia. International Islamic University Malaysia.

Daud, M. (2019). Internet Content Regulation: Contemporary Legal and Regulatory Issues in the Changing Digital Landscape. Gombak: IIUM Press.

Daud, M., \& Zulhuda, S. (2020). Regulating the spread of false content online in Malaysia: Issues, challenges and the way forward. International Journal of Business and Society, 21(S1), 32-48.

Faruqi, S. S. (2008). Document of Destiny: The Constitution of the Federation of Malaysia (1st Editio). Petaling Jaya: Star Publications (Malaysia) Bhd.

Fernandez, J. (2019). Malaysia's Anti-Fake News Act: A cog in an arsenal of anti-free speech laws and a bold promise of reforms. Pacific Journalism Review, 25(1 \& 2), 173-192.

Gelfert, A. (2020). Fake News : A Definition Fake News : A Definition.

Haron, H. H., Shuaib, F. S., \& Arsat, N. (2019). The Proposed Malaysian Press Council in the Digital Era: An Idea Past Its Time? In 8th International Conferance on Law and Society (ICLAS 2019). Istanbul.

Hasim, M. S., \& Merican, A. M. (2002). The Formation of A Media Council: The Experience of Malaysia. Jurnal Komunikasi. 
Human Rights Watch. (2015). Creating a Culture of Fear : The Criminilization of Peaceful Expression in Malaysia.

Kleinsteuber, H. J. (2004). Self-regulation, Co-regulation, State Regulation. The Media Freedom Internet Cookbook, $61-75$. https://www.osce.org/fom/13844?download=true\%0Ahttp://www.osce.org/fom/13844?

Lazer, D. M. J., Baum, M. A., Benkler, Y., Berinsky, A. J., Greenhill, K. M., Menczer, F., Miriam, J.M., Nyhan, B., Pennycook, G., Rothschild, D., Schudson, M., Sloman, S. A., Sunstein, C. R., Thorson, E. A., Watss, D. J., Zittrain, J. L. (2018). The science of fake news. Science, 359(6380), 10941096. https://doi.org/10.1126/science.aao2998

Leong, T. (2020). Fake News Makes KL Govt's Task of Fighting Virus Even Tougher. The Straits Times. https://www.straitstimes.com/asia/se-asia/fake-news-makes-kl-govts-task-of-fighting-virus-eventougher

Mohd Yatid, M. (2019). Truth Tampering Through Social Media: Malaysia's Approach in Fighting Disinformation \& Misinformation. The Indonesian Journal of Southeast Asian Studies, 2(2), 203230. https://doi.org/10.1355/9789814377447-001

Nawang, N. I., \& Mustaffa, A. (2017). Online News Portals in Malaysia: Should They Be Subjected to the Existing Traditional Media Laws? World Applied Sciences Journal, 35((9)), 1718-1722. https://doi.org/10.5829/idosi.wasj.2017.1718.1722

Pennycook, G., Mcphetres, J., Zhang, Y., \& Rand, D. G. (2020). Fighting COVID-19 misinformation on social media : Experimental evidence for a scalable accuracy nudge intervention, 1-24.

Posetti, J., \& Matthews, A. (n.d.). A short guide to the history of "fake news" and disinformation $A$ Learning Module For Journalists And Journalism Educators. https://doi.org/10.1207/S15327728JMME1502_3

Printing Presses and Publications Act 1984 s. 8(A) (My., n.d.). Retrieved from http://www.moha.gov.my/images/maklumat_bahagian/PQ/Act301.pdf

Sufian Shuaib, F., \& Hakimi Haron, H. (2019). The Continuing Saga of the Proposed Malaysian Press Council: A Boone or Bane? [2019] 4 MLJ cxxvii. Malayan Law Journal, 4, cxxvii.

The Star. (2020). Saifuddin: 205 fake news items 'busted' by Communications Ministry over four weeks. August 14, 2020, https://www.thestar.com.my/news/nation/2020/04/21/saifuddin-205-fake-newsitems-busted-by-communications-ministry-over-four-weeks

Wariya, C. (2017). Krisis dan Strategi : Cabaran Kewartawanan dan Media Era Digital. Cyberjaya: Malaysian Press Institute.

Zainul, H. (2020a). Malaysia's Infodemic and Policy Response. ISIS Policy Brief, (2-20), 1-4. https://www.isis.org.my/wp-content/uploads/2020/06/POLICY-BRIEF_MALAYSIAINFODEMIC-AND-POLICY-RESPONSE.pdf

Zainul, H. (2020b). Media freedom and fake news during the time of Covid-19. August 14, 2020, https://www.isis.org.my/2020/04/15/media-freedom-and-fake-news-during-the-time-of-covid-19/ 